\title{
Børsrakett forlenger livet?
}

ㄴ.

Engelsk oversettelse av hele artikkelen på www.tidsskriftet.no
Mandag 6. juni 2011 sendte det norske bioteknologiselskapet Algeta ut en gledelig melding. Utprøvningen av medikamentet Alpharadin på over 900 pasienter med prostatakreft hadde gitt «entydig positive resultater». Studien, som opprinnelig var planlagt å pågå til 2012, ble derfor avsluttet før tiden (1). «Vi er både glade og stolte,» uttalte teknologidirektør Thomas Ramdahl til Aftenposten. «Dette er veldig spennende for oss og ikke minst for kreftpasienter som kan få hjelp. De kan leve lenger, og de kan unngå sterke bivirkninger,» sa han. «Markedspotensialet er av Blockbuster-format» (1). Nyheten utløste en kursoppgang på $37 \%$ på Oslo Børs samme dag. Verdien av Algeta ved børsens stengetid var rundt 7,91 milliarder kroner, og de åtte lederne i selskapet kunne glede seg over opsjoner som ville utløst 320 millioner kroner i gevinst (1). Dagen etter hadde avisene førstesidetitler som Børsrakett forlenger livet (Dagens Næringsliv) og Styrtrike på kreftmedisin (Aftenposten).

Tre uker senere hadde Aftenposten en femsiders reportasje om saken (2). Avisens journalister rapporterte fra det avgjørende møtet i Chicago 3. juni 2011: «Thomas Ramdahl og Gillies O'Bryan-Tear fra det norske kreftmedisinselskapet Algeta sitter i en korridor. Over femten års arbeid og investeringer på én milliard kroner har ledet frem til denne korridoren. Og til en avgjørelse bak en av de lukkede dørene. Timene går mens de to venter. Men de har ventet i mange år allerede. I tre år har nemlig 922 pasienter ved 140 sykehus i 19 land deltatt $\mathrm{i}$ testingen av selskapets medisin Alpharadin. En medisin mot prostatakreft med spredning til skjelettet. Bare siste fase av utprøvingen har kostet en halv milliard kroner. I Chicago denne ettermiddagen skal et ekspertråd med fem medisinske akademikere svare på om virkningene er dokumentert godt nok. Som teknisk direktør og medisinsk direktør vet de to hva et «ja» fra ekspertrådet vil bety for det norske selskapet. Formannen i rådet åpner døren. De får klarsignal til å komme inn. Tre av ekspertene sitter i rommet. De to andre er på videolink fra London. Beskjeden fra ekspertene kommer muntlig: Resultatene holder. Medisinen har effekt og forlenger livet til dødssyke pasienter med prostatakreft. Dere kan avslutte studien ett år før tiden. Ramdahl ringer raskt til selskapets sjef Andrew Kay, før han like raskt avbryter Chicago-oppholdet han akkurat har begynt på og drar tilbake til Norge.»

Dramaturgien er effektfull, konklusjonen krystallklar - klart for børsbonanza! Riktignok uttalte professor Sophie D. Fosså til avisen at hun ikke var like sikker som Algeta på den nye medisinen deres. «Jeg er fremdeles litt skeptisk til disse resultatene. Jeg vil ikke gjøre medikamentet urett, men jeg skjønner det bare ikke,» sa Fosså (2).

Mens de som fikk placebobehandling under utprøvningen levde 11,2 måneder (median), overlevde Alpharadin-brukerne i 14 måneder. Midlet skulle altså forlenge medianlevetiden med knappe tre måneder. Det kan virke beskjedent, men for pasientene kan hver dag telle. Mesteparten av fremgangen i medisinsk forskning foregår jo på denne måten - med små skritt som til sammen og over år gir større effekter. Dessuten forsikret forskerne at resultatene kan forbedres på «mange måter»: Ved å identifisere pasienter som er bedre egnet for behandlingen, komme inn tidligere i sykdomsforløpet og ved å kombinere Alpharadin med andre medikamenter (1). Alpharadin kan i prinsippet også være virksomt mot andre kreftformer.
Viktigst for pasientene er håpet om et lengre liv og færre bivirkninger. Det er heller ikke hverdagskost at norske bioteknologiselskaper har faglig og kommersiell suksess av et slikt format. Men hvordan kom dette egentlig i stand? Ifølge avisreferatet hadde altså et ekspertråd med fem medisinske akademikere vurdert resultatene, og entydig, skjønner vi, kommet til at resultatene holdt. Ja, ikke bare det, men i en slik grad at studien ble avbrutt før tiden fordi resultatene var så «overbevisende at det ikke lenger kan forsvares å la pasienter som deltar i studien få narremedisin (placebo)» (3).

Algeta-saken er ikke enestående. Det ser ut til å bli stadig vanligere at resultater fra pågående studier blir offentliggjort via f.eks. pressemeldinger fra firmaene. Den tradisjonelle måten å gjøre det på er at forskerne publiserer vitenskapelige artikler. Manuskriptene gjennomgår da omfattende faglig gransking og redaksjonell bearbeiding, forfatterne må ofte fremstille funnene mer nøkternt, konklusjonene blir neddempet eller kanskje til og med snudd opp ned. Vitenskapelige artikler blir finlest av forskere og andre fagpersoner, noe som oftest medfører ytterligere debatt og drøfting i tidsskriftenes leserbrevspalter. Funn fra én studie må vanligvis bekreftes i flere undersøkelser før man kan anta at de er gyldige. Bevacizumab (Avastin) i behandling av brystkreft er et aktuelt eksempel på dette. Medikamentet ble registrert etter én overbevisende studie som viste forlenget effekt på surrogatmarkøren progredieringsfri overlevelse. Senere studier har vist mindre gevinst på slik overlevelse og ingen på samlet overlevelse. Amerikanske legemiddelmyndigheter (FDA) kommer trolig til å trekke godkjenningen (4).

Vitenskapelig publisering kan virke unødig kronglete og tidkrevende, noe som harmonerer dårlig med børsenes hektiske rytme. Problemet ligger imidlertid ikke her. Børser lever godt med rykter og mangelfull informasjon, men det gjør ikke kunnskapsbasert medisin. Det er mange måter vitenskap kan formidles og diskuteres på. Pressemeldinger og børsmeldinger hører ikke til dem.

I slutten av august 2011 kom meldingen om ny kraftig kursoppgang for Algeta fordi Alpharadin var blitt innvilget såkalt fast track-prosedyre av FDA. Dermed kan legemidlet være klart for salg i USA tidlig i 2012 (5). Vi må selvsagt håpe at de «entydig positive» resultatene med Alpharadin viser seg å holde stikk, både for pasienter, forskere og investorer. Men det vil tiden vise - etter at resultatene er publisert.

\section{Erlend Hem}

erlend.hem@medisin.uio.no

Erlend Hem (f. 1970) er dr.med. og assisterende redaktør i Tidsskriftet.

\footnotetext{
Litteratur

1. Sunnanå LM, Lynum F. Ny kreftmedisin ga kursrakett. Aftenposten 7.6.2011: 2-3. www.aftenposten.no/okonomi/innland/article4141291.ece (15.8.2011).

Foss AB, Sunnanå LM. Markedskreften. Aftenposten 25.6.2011: 17-21.

3. Dugstad L, Nikolaisen P-I, Nyheim A. Lever lenger med ny medisin. Dagens Næringsliv 7.6.2011: 6-7

4. Jones A, Ellis P. Potential withdrawal of bevacizumab for the treatment of breast cancer. BMJ 2011; 343: d4946. www.bmj.com/content/343/bmj.d4946.long (15.8.2011).

5. Jensen TC. Vinneren Algeta. Dagens Næringsliv 24.8.2011: 41
} 